the ground, one being mistreated and threatened in the slender poplar tree, and only one left in the nesit. The lad shaking the tree stopped, climbed the tree, retrieved the young owl and number three was banded.

Meanwhile mother owl hooted ferociously in deep tones, and her vocal threats became more fearsome. Suddenly she flew in and slashed my left hand, then perched once more to the south as I was busily preparing to climb down.

Blackness had enveloped the spruce bush, but the horizon and silhouetted treetops were still visible. The big yellow eyes of the second adult owl looked fierce as W-H-I-S-H he rushed by. I turned my eyes away from the parent owls for five seconds to find the clasp on my safety belt so that I could climb down more quickly. When I looked up a black figure was speeding swiftly from the shadows and smashing into my face with her talons, her whole body's momentum behind them. One talon pierced my left eye, blinding me instanitly. It had only taken the owl two seconds to fly $\mathbf{5 0}$ feet from her aerial perch to strike me, and I had not seen her in time to defend myself.

One hour later in hospital a wellqualified surgeon sutured the laceration and told me that any vision in the injured eye would develop by the grace of God and not by his skill. After the first month in hospital vision had improved to about $5 \%$; today, on July 16, vision in the injured eye has improved greatly to about 20-25\%, with good peripheral vision. I have had to lead a quiet life during the past two months and of course I missed my Grade 12 finals.

From my experience, and in the besit interests of those who share my enthusiasm for winged predators, I make the following recommendations:

(1) Never climb a Horned Owl's nest at night, especially if young are present.

(2) When climbing up to a Horned Owl, Goshawk, Pigeon Hawk or even a Crow's nest wear a safety mask, either a hockey goalie's plastic mask or a strong-meshed fencer's mask.

(3) Wear a heavy pair of leather gloves, preferably welder's gloves used in falconry.

(4) Wear climbing spurs if necessary.

(5) Wear a tough leather jacket.

(6) Break off a branch on the way up to a Horned Owl's nest in order to strike the female if she attacks, as this will usually discourage further attacks.

Horned Owls disturbed at their nest by humans mean business, and their maternal instinct is so strong that they will risk their lives to protect their young. They are crafty in their attack strategy and may strike from unexpected angles, ripping at any flesh they can seize. The value of a mask for protection is thus immeasurable.

(Editor's Note: We are pleased to note that Dick's enthusiasm for wildlife has not waned in spite of this personal injury.)

\title{
Hybrid Duck
}

A challenging problem in identification was posed by the appearance of an unusual duck on Wascana Lake, June 1, 1959 (Blue Jay, XVII:98). The skin and carcass were sent from the Saskatchewan Museum of Natural History to Dr. Philip S. Humphrey of the Peabody Museum of Natural History at Yale University, who wrote in reply to Dr. Nero:

"I received the skin and carcass of the hybrid duck last week. It is certainly a very curious beast. I have examined it carefully and discussed the matter in detail with Dillon Rip- ley. He and I both agree that the bird can only be a Muscovy-Mallard hybrid. The fact that the bird is a female accounts for its small size. The bird clearly has far more Muscovy in it than Mallard, although the beak is more like that of a dabbling duck than that of a Muscovy. Quite frankly, detailed comparison of specimens did not enable me to tell whether the dabbling duck member of the cross was Mallard or Black. Our main evidence for thinking that it must have been a Mallard is distributional rather than morphological." 